\title{
ANALISIS KETERKAITAN ANTARA INDEKS PEMBANGUNAN MANUSIA DAN PDRB PER KAPITA DI INDONESIA
}

\author{
Ryan Ezkirianto ${ }^{1}$ dan Muhammad Findi $\mathrm{A}^{2}$ \\ ${ }^{1}$ Mahasiswa Sarjana Ilmu Ekonomi, FEM IPB \\ ${ }^{2}$ Staf Pengajar FEM IPB
}

Artikel diterima Maret 2013

Artikel disetujui untuk dipublikasikan Juli 2013

\begin{abstract}
This paper attempts to analyse the two-way relationship between human development and economic growth for 33 provinces in Indonesia during six years period: 2006-2011. The various links in each variabel were analyzed with description analysis, such education, government spending on health and education, total government expenditure, income distribution, and density. The quantitatif analysis used two-stage least square (2SLS) method. The result shows that there is a strong positive relationship between human development index and GDRP per capita, while education, government spending on health and education, total government expenditure, and income distribution are the important links determining the strength of relationship between human development and economic growth.
\end{abstract}

Keywords: human development, economic growth

\begin{abstract}
ABSTRAK
Penelitian ini menganalisis hubungan dua arah antara pembangunan manusia dan pertumbuhan ekonomi terhadap 33 provinsi di Indonesia pada periode 2006-2011. Faktor penghubung pada masing-masing persamaan dianalisis berdasarkan beberapa penelitian empiris, seperti rata-rata lama sekolah, belanja pemerintah bidang pendidikan dan kesehatan, total pengeluaran pemerintah, distribusi pendapatan, dan kepadatan penduduk. Data panel dianalisis dengan metode two-stage least square (2SLS). Hasil penelitian menunjukkan bahwa terdapat hubungan positif yang signifikan antara indeks pembangunan manusia dan PDRB per kapita, ketika rata-rata lama sekolah, belanja pemerintah bidang pendidikan dan kesehatan, total pengeluaran pemerintah, serta distribusi pendapatan merupakan variabel penting yang menjelaskan kekuatan hubungan antara pembangunan manusia dan pertumbuhan ekonomi.
\end{abstract}

Kata kunci: pembangunan manusia, pertumbuhan ekonomi

\section{PENDAHULUAN}

Pembangunan manusia merupakan salah satu faktor penting dalam pertumbuhan ekonomi. Sumberdaya manusia yang berkualitas memiliki produktifitas tinggi sehingga mampu meningkatkan efisiensi kegiatan ekonomi dan secara agregat dapat memengaruhi pertumbuhan ekonomi (Tjiptoherijanto,
1996). Ranis (2006) menyatakan bahwa pembangunan manusia merupakan kontributor dari stabilnya proses pertumbuhan ekonomi dan tidak hanya berkontribusi terhadap tujuan fundamental pembangunan, tetapi juga sebagai faktor penting terhadap pertumbuhan ekonomi sepanjang waktu.

Demikian pula pertumbuhan ekonomi menyediakan tingkat 
pendapatan yang tinggi sebagai syarat pemenuhan kebutuhan dasar dan perbaikan kualitas modal manusia. Stabilnya tingkat pertumbuhan ekonomi juga menciptakan efek repetisi jangka panjang yang penting dalam peningkatan pembangunan manusia. Peningkatan pendapatan sebagai instrumen pembesar kapasitas pemerintah dalam penyediaan fasilitas sosial, pendidikan, dan kesehatan mampu meningkatkan pembangunan manusia pada periode tertentu. Dengan demikian, pembangunan manusia dan pertumbuhan ekonomi merupakan faktor input sekaligus tujuan utama dari proses pembangunan.

Berdasarkan data dari Badan Pusat Statistik (BPS), Indonesia mengalami masalah ketidakmerataan dalam pembangunan manusia yang diukur oleh indeks pembangunan manusia (IPM). Indeks ini mencerminkan kualitas modal manusia yang diukur dari indikator tingkat pendidikan, kesehatan, dan daya beli masyarakat. Nilai rata-rata IPM periode 2006-2011 untuk seluruh provinsi (Gambar 1) memperlihatkan bahwa Provinsi DKI Jakarta, Sulawesi Utara, dan Riau memiliki IPM tertinggi dengan nilai masing-masing sebesar 77.1, 75.4, dan 75.3. Sedangkan Provinsi Papua, Nusa Tenggara Barat, dan Nusa Tenggara Timur memiliki IPM terendah dengan nilai masing-masing 64.2, 64.5, dan 66.3. Kesenjangan pembangunan manusia antarwilayah Indonesia Bagian Barat (IBB) dan Indonesia Bagian Timur (IBT) juga terlihat dari fakta bahwa 10 provinsi yang terendah nilai indeks pembangunan manusianya seluruhnya berasal dari wilayah IBT, yaitu Provinsi Papua, Nusa Tenggara Barat, Nusa Tenggara Timur, Papua Barat, Kalimantan Barat, Maluku Utara, Sulawesi Barat, Kalimantan Selatan, Sulawesi Tenggara, dan Gorontalo. Sedangkan provinsi-provinsi dari wilayah IBB secara umum menempati posisi sedang hingga tinggi, seperti Provinsi DKI Jakarta, Riau, Yogyakarta, dan
Kepulauan Riau. Hanya beberapa Provinsi dari IBT yang tergolong sebagai provinsi dengan IPM tinggi, yaitu Provinsi Sulawesi Utara, Kalimantan Timur, dan Kalimantan Tengah, sedangkan yang tergolong IPM sedang didominasi oleh provinsi dari wilayah IBB.

Pertumbuhan ekonomi juga merupakan faktor penting sebagai gambaran dari pendapatan masyarakat yang dilihat melalui indikator PDRB per kapita. Nilai rata-rata PDRB per kapita seluruh provinsi (Gambar 2) menunjukkan bahwa provinsi DKI Jakarta, Kalimantan Timur, Riau, serta Kepulauan Riau memiliki pertumbuhan ekonomi teringgi. Sedangkan 4 provinsi dari wilayah Indonesia Bagian Timur, yaitu Provinsi Maluku Utara, Maluku, Gorontalo, serta Nusa Tenggara Timur memiliki PDRB per kapita terendah dibanding provinsi lain. Nilai PDRB per kapita provinsi tertinggi (DKI Jakarta) yang mencapai 15 kali lebih tinggi dari provinsi dengan PDRB per kapita terendah (Nusa Tenggara Timur) menunjukkan kesenjangan pendapatan yang tinggi antarwilayah di Indonesia. Kecepatan pertumbuhan ekonomi yang tidak seimbang antarwilayah juga terlihat pada pertumbuhan nilai PDRB per kapita provinsi DKI Jakarta yang tumbuh sebesar 1,710 ribu rupiah per tahun sedangkan provinsi Nusa Tenggara Timur hanya tumbuh sejumlah 79 ribu rupiah per tahun. Data tersebut menunjukkan kesenjangan antarprovinsi yang sangat signifikan baik dalam hal jumlah nominal maupun kecepatan pertumbuhan PDRB per kapita.

Data Badan Pusat Statistik (BPS) tahun 2011 memperlihatkan Provinsi Yogyakarta memiliki IPM sebesar 76.32 yang merupakan tertinggi ke-4 nasional, namun memiliki PDRB per kapita yang relatif rendah, yaitu 6,345 ribu rupiah. Contoh lain yaitu pada Provinsi Papua Barat yang memiliki PDRB per kapita sebesar 15,102 ribu rupiah yang 
merupakan tertinggi ke-5 nasional, namun hanya memiliki nilai IPM sebesar 69.65, berada di peringkat 29 dari 33 provinsi. Hal tersebut menunjukkan bahwa terdapat suatu kondisi looped economic growth, yaitu ketika pertumbuhan ekonomi tinggi tidak disertai dengan pembangunan manusia yang tinggi pula, serta kondisi looped human development yang terindikasi ketika pembangunan manusia tinggi tidak diikuti oleh pertumbuhan ekonomi yang tinggi.

Pemerintah daerah di Indonesia sebagai penentu kebijakan memiliki peran penting dalam mengalokasikan sumberdaya sebagai input pembangunan wilayah, khususnya setelah ditetapkannya Undang-undang no 22 tahun 1999 yang direvisi menjadi Undang-undang no 32 tahun 2004 tentang Otonomi Daerah, dimana kebijakan pembangunan daerah diserahkan kepada masing-masing pemerintah daerah, sedangkan pemerintah pusat hanya sebagai pengawas atau pengontrol kebijakan. Beberapa wilayah berorientasi terhadap pertumbuhan ekonomi sebagai strategi pembangunannya, sementara beberapa wilayah lain memberikan perhatian relatif lebih besar terhadap kebijakan yang berkaitan dengan fasilitas sosial dan peningkatan kualitas pembangunan manusia. Keragaman sumberdaya, kapabilitas, kebutuhan, serta potensi di masing-masing wilayah memengaruhi strategi pembangunan yang dilakukan oleh pemerintah daerah. Perumusan kebijakan yang kurang tepat dapat mengurangi efisiensi dan efektifitas program kebijakan yang telah disiapkan pemerintah daerah.

Oleh sebab itu perlu dianalisis seberapa besar keterkaitan antara pembangunan manusia dengan pertumbuhan ekonomi pada provinsiprovinsi di Indonesia, apakah keduanya saling berpengaruh positif, negatif, atau tidak terkait sama sekali, serta dikaji pula faktor apa saja yang berpengaruh terhadap pembangunan manusia serta pertumbuhan ekonomi suatu wilayah. Penelitian ini bertujuan untuk: menganalisis hubungan keterkaitan antara indeks pembangunan manusia $\left(H D I_{i t}\right)$ dan PDRB per kapita $\left(Y_{i t}\right)$; menganalisis pengaruh rata-rata lama sekolah $\left(E D U_{i t}\right)$, belanja pemerintah bidang pendidikan dan kesehatan $\left(\right.$ PSPEND $\left._{i t}\right)$, serta PDRB per kapita $\left(Y_{i t}\right)$ terhadap indeks pembangunan manusia $\left(H D I_{i t}\right)$; dan menganalisis pengaruh total pengeluaran pemerintah $\left(G E_{i t}\right)$, indeks gini $\left(G R_{i t}\right)$, kepadatan penduduk $\left(D E N S_{i t}\right)$ dan indeks pembangunan manusia $\left(H D I_{i t}\right)$ terhadap PDRB per kapita $\left(Y_{i t}\right)$.

\section{METODE PENELITIAN}

Model yang dianalisis adalah model simultan dari persamaan indeks pembangunan manusia dan PDRB per kapita. Pengujian simultanitas dilakukan dengan uji spesifikasi hausman (Hausman, 1978) serta identifikasi order condition untuk menentukan metode analisis yang digunakan (Pindyck dan Rubinfeld (1998). Selanjutnya dilakukan uji $F$-statistik dan uji hausman untuk menentukan metode estimasi yang tepat antara fixed effect dan random effect.

\section{Jenis dan Sumber Data}

Jenis data yang digunakan adalah data sekunder yang bersumber dari Badan Pusat Statistik dan Kementerian Keuangan RI. Secara rinci jenis-jenis data yang diperlukan dan sumbernya untuk setiap variabel yang diamati disajikan dalam Tabel 1.

\section{Spesifikasi Model}

Penelitian ini mengkaji hubungan dua arah antara pembangunan manusia dan pertumbuhan ekonomi. Pemilihan model diadaptasi berdasarkan penelitian empiris. Model yang akan dijelaskan adalah model persamaan simultan yang terdiri dari persamaan pembangunan manusia dan persamaan pertumbuhan ekonomi. 


\section{a. Model Persamaan Pembangunan Manusia}

Analisis hubungan dua arah antara pembangunan manusia membutuhkan variabel yang dapat dijadikan parameter penelitian dengan baik. Basri dan Munandar (2009) menyatakan bahwa indeks pembangunan manusia (IPM) merupakan proksi yang tepat untuk menggambarkan kondisi pembangunan manusia.

Tingkat pendidikan masyarakat menentukan pola konsumsi terhadap jenis barang yang berkontribusi langsung terhadap peningkatan modal manusia, seperti makanan serta fasilitas sanitasi yang baik. Peningkatan kondisi kesehatan dan gizi yang baik telah memberi bukti memiliki pengaruh langsung terhadap produktivitas pekerja (Ranis et al. 2000). Tingkat pendidikan yang baik dapat meningkatkan kondisi sanitasi yang lebih baik bagi seluruh anggota keluarga dan makanan yang lebih bergizi. Selain itu, belanja pemerintah bidang pendidikan dan kesehatan memperluas akses masyarakat terhadap edukasi serta pelayanan kesehatan yang memadai. Belanja pemerintah daerah bidang pendidikan dan kesehatan menyediakan akses masyarakat terhadap fasilitas pemenuhan kebutuhan dasar untuk pembangunan manusia. Tingkat pendidikan dan kesehatan yang baik dapat meningkatkan kualitas modal manusia. Dengan demikian, kedua faktor tersebut diduga berpengaruh positif terhadap pembangunan manusia.

Tingkat PDRB per kapita juga diduga memengaruhi indeks pembangunan manusia. Pengeluaran penduduk yang semakin tinggi menyebabkan tingkat pemenuhan kebutuhan dasar penduduk semakin baik. Hal tersebut mendorong tingkat konsumsi untuk pendidikan dan kesehatan semakin meningkat, sehingga berpengaruh terhadap indeks pembangunan manusia di suatu wilayah.
Berdasarkan beberapa argumen tersebut, maka model pembangunan manusia dalam penelitian ini adalah sebagai berikut:

$H D I_{\text {it }}=\alpha_{0}+\alpha_{1} E D U_{\text {it }}+\alpha_{2} P S P E N D_{\text {it }}+\alpha_{9} Y_{\text {it }}+e_{\text {it }}$

keterangan:

$\begin{aligned} \alpha_{i}= & \begin{array}{l}\text { konstanta } / \text { intersep } \\ \text { provinsi } i\end{array} \\ H D I_{i t}= & \text { indeks pembangunan } \\ & \text { manusia; } \\ \text { PSPEND }_{i t}= & \text { belanja pemerintah } \\ & \text { daerah } \begin{array}{r}\text { bidang } \\ \text { pendidikan dan }\end{array} \\ & \text { kesehatan provinsi } i \\ & \text { tahun } t \text {; dalam log } \\ = & \text { rata-rata lama sekolah } \\ & \text { usia 15 tahun ke atas } \\ & \text { provinsi } i \text { tahun } t ; \\ & \text { dalam tahun } \\ = & \text { PDRB per kapita } \\ & \text { provinsi } i \text { tahun } t ; \\ & \text { dalam log } \\ Y_{i t} & \text { error term }\end{aligned}$

\section{b. Model Persamaan Pertumbuhan} Ekonomi

Pertumbuhan ekonomi dinyatakan oleh Pendapatan Regional Domestik Bruto (PDRB) per kapita karena menunjukkan tingkat pendapatan individu secara rata-rata. Ramirez et al. (1998) memasukkan variabel investasi fisik, belanja pemerintah, serta indeks pembangunan manusia sebagai input persamaan pertumbuhan ekonomi.

Pengeluaran pemerintah meningkatkan akses masyarakat terhadap fasilitas pembangunan sehingga proses kegiatan ekonomi berjalan semakin efisien dan produktif. Pertumbuhan ekonomi yang diikuti distribusi pendapatan yang merata merupakan indikator kesejahteraan serta pembangunan jangka panjang yang stabil. Kepadatan penduduk juga diduga berperan dalam meningkatkan produktivitas sebagai gambaran dari tingkat aglomerasi yang meningkatkan efisiensi produksi. 
Selain itu perlu dianalisis pula aspek spasial serta tingkat pemerataan pendapatan antarwilayah sebagai faktor yang memengaruhi pertumbuhan ekonomi. Ketiga faktor tersebut diduga memengaruhi pertumbuhan ekonomi sehingga perlu dianalisis seberapa besar pengaruhnya terhadap proses pembangunan wilayah di Indonesia.

Berdasarkan penjelasan tersebut, maka dapat diambil suatu model persamaan pertumbuhan ekonomi sebagai berikut:

$$
\begin{aligned}
Y_{i t}= & \beta_{0}+\beta_{1} G E_{i t}+\beta_{2} G R_{i t}+\beta_{3} D E N S_{i t}+ \\
& \beta_{4} H D I_{i t}+u_{i t}
\end{aligned}
$$

keterangan:

$$
\begin{aligned}
& \beta_{i} \quad=\text { konstanta /intersep provinsi } \\
& Y_{i t} \quad=\text { PDRB per kapita provinsi } i \\
& \text { tahun } t \text {; dalam } \log \\
& G E_{i t} \quad=\text { total pengeluaran } \\
& \text { pemerintah per jumlah } \\
& \text { penduduk provinsi } i \\
& \text { tahun } t \text {; dalam } \log \\
& G R_{i t} \quad=\text { indeks gini provinsi } i \text { tahun } \\
& t \\
& D E N S_{i t} \quad=\text { kepadatan penduduk } \\
& \text { provinsi } i \text { tahun } t \text {; dalam } \\
& \log \\
& H D I_{i t} \quad=\text { indeks pembangunan } \\
& \text { manusia provinsi } i \text { tahun } t \text {, } \\
& u_{i t}=\text { error term }
\end{aligned}
$$

\section{HASIL DAN PEMBAHASAN}

\section{Identifikasi dan Spesifikasi Model}

Perhitungan order condition menunjukkan jumlah variabel eksogen melebihi jumlah variabel endogen dalam model, maka dapat disimpulkan bahwa kedua persamaan overidentified, sehingga estimasi model data panel menggunakan two-stages least square (2SLS) (Gujarati, 2004). Sementara hasil uji hausman menunjukkan t-hitung residual $\widehat{w_{\text {it }}}$ sebesar 4.941 yang lebih besar dari t-tabel $(193 ; 0.01)$ sebesar 3.090. Dengan demikian, hasil uji menyatakan bahwa variabel residual $\widehat{w_{\text {it }}}$ signifikan memengaruhi $Y$ pada tingkat $\alpha=0.01$. Dengan demikian dapat dibuktikan bahwa terdapat hubungan simultanitas antara variabel $Y$ dan variabel $H D I$.

\section{Pemilihan Model Data Panel}

\subsection{Uji $\boldsymbol{F}$-statistik}

Hasil uji $F$-statistik (Tabel 2) menunjukkan bahwa nilai $F$-statistik persamaan $H D I$ dan persamaan $Y$ melebihi nilai $F$-tabel. Dengan demikian, hipotesis nol (model common effect) ditolak sehingga persamaan $H D I$ dan $Y$ lebih sesuai diestimasi menggunakan model fixed effect.

\subsection{Uji hausman}

Hasil uji hausman (Tabel 3) menunjukkan bahwa nilai chi-square $\left(\chi^{2}\right)$ hasil perhitungan melebihi nilai $\chi^{2}$ tabel. Dengan demikian, hipotesis nol (model random effect) ditolak sehingga model yang lebih sesuai untuk mengestimasi kedua persamaan tersebut adalah fixed effect.

\section{Persamaan manusia (HDI)}

Hasil estimasi dengan menggunakan fixed effect 2SLS dengan weighted cross section dan white cross section coefficient covariance method (Tabel 4) memperlihatkan bahwa seluruh variabel bebas memengaruhi variabel $H D I$ secara signifikan.

\subsection{Uji hipotesis persamaan $H D I$}

Uji hipotesis dilakukan untuk melihat signifikansi secara statistik parameter yang ditemukan melalui estimasi. Terdapat dua jenis pengujian, yakni (1) pengujian hipotesis individual (t-test), dan (2) pengujian hipotesis berganda $(F$-test)

- Pengujian hipotesis individual (t-test)

Hasil estimasi (Tabel 4) memperlihatkan variabel EDU memiliki pengaruh yang signifikan pada tingkat kesalahan 5\% yang ditunjukkan oleh nilai $p$-value di bawah 0.05. Sedangkan variabel 
PSPEND dan $Y$ memiliki pengaruh yang signifikan pada tingkat kesalahan $1 \%$ yang ditunjukkan oleh nilai $p$-value di bawah 0.01. Dengan demikian, hipotesis nol bahwa tidak adanya pengaruh individual dari masing-masing variabel dapat ditolak. Baik ratarata lama sekolah, belanja pemerintah bidang pendidikan dan kesehatan, maupun PDRB per kapita memiliki dampak yang signifikan terhadap indeks pembangunan manusia.

- Pengujian hipotesis berganda (F-test)

Pada model regresi statistik uji $F$ untuk signifikansi secara umum (overall significance) adalah sebesar 296.5714. Statistik ini dibandingkan dengan nilai kritis dengan derajat bebas $q=3$ (numerator) dan $n-k-1=198-$ $3-1=194$ (denominator) sebesar 3.88. Dengan demikian, hipotesis nol bahwa secara bersama variabel penjelas tidak memberikan nilai tambah informasi dapat ditolak.

\subsection{Uji kelaikan suai (goodness of fit) persamaan $\mathrm{HDI}$}

Hasil estimasi (Tabel 4) memperlihatkan nilai adjusted $R$ squared sebesar 0.99 yang berarti bahwa variasi indeks pembangunan manusia $(H D I)$ dapat dijelaskan bersama-sama oleh variasi rata-rata lama sekolah $(E D U)$, belanja pemerintah bidang pendidikan dan kesehatan (PSPEND), dan PDRB per kapita $(Y)$ sebesar $99 \%$ dan sisanya dijelaskan oleh variabel lain di luar model.

\subsection{Interpretasi parameter hasil estimasi \\ Hasil estimasi persamaan dengan metode 2SLS menghasilkan}

persamaan HDI dengan model matematika sebagai berikut:

$$
\begin{gathered}
H D I_{i t}=\alpha_{0 i}+0.469 E D U_{i t}+0.298 \\
P S P E N D_{i t}+8.455 Y_{i t}+e_{i t}
\end{gathered}
$$

keterangan:

$\alpha_{0 i}=$ konstanta masing-masing provinsi $i$ (Tabel 5)

Secara umum nilai koefisien variabel bebas bertanda positif, yang berarti bahwa variabel rata-rata lama sekolah $(E D U)$, belanja pemerintah bidang pendidikan dan kesehatan (PSPEND), dan PDRB $(Y)$ per kapita berpengaruh positif terhadap indeks pembangunan manusia. Koefisien variabel $E D U$ sebesar 0.469 berarti bahwa setiap peningkatan 1 tahun rata-rata lama sekolah terjadi peningkatan indeks pembangunan manusia regional sebesar $0.469 \%$ dengan asumsi variabel lain tetap (cateris paribus). Koefisien variabel PSPEND sebesar 0.298 berarti bahwa setiap peningkatan $1 \%$ belanja pemerintah bidang pendidikan dan kesehatan maka terjadi peningkatan sebesar $0.298 \%$ pada indeks pembangunan manusia dengan asumsi variabel lain tetap (cateris paribus). Koefisien variable $Y$ sebesar 8.455 berarti bahwa setiap peningkatan $1 \%$ PDRB per kapita maka terjadi peningkatan sebesar $8.455 \%$ pada indeks pembangunan dengan asumsi variabel lain tetap (cateris paribus).

\section{Persamaan PDRB per kapita $(Y)$}

Hasil estimasi (Tabel 6) dengan menggunakan fixed effect 2SLS dengan weighted cross section dan white cross section coefficient covariance method memperlihatkan bahwa seluruh variabel bebas memengaruhi variabel $Y$ secara signifikan, kecuali variabel DENS. Hasil estimasi lengkap tercantum dalam Lampiran 3.

\subsection{Uji hipotesis persamaan $Y$}

Uji hipotesis dilakukan untuk melihat signifikansi secara statistik 
parameter yang ditemukan melalui estimasi. Terdapat dua jenis pengujian, yakni (1) pengujian hipotesis individual ( $t$-test), dan (2) pengujian hipotesis berganda $(F$-test).

$\begin{array}{lll}\text { - } & \text { Pengujian } & \text { hipotesis } \\ \text { individual ( } t \text {-test) } & & \\ \text { Hasil estimasi (Tabel 6) }\end{array}$ memperlihatkan variabel $G E, G R$, dan $H D I$ memiliki pengaruh yang signifikan pada tingkat kesalahan $1 \%$ yang ditunjukkan oleh nilai $p$ value di bawah 0.01. Dengan demikian, hipotesis nol bahwa tidak adanya pengaruh individual dari masing-masing variabel tersebut dapat ditolak. Baik total pengeluaran pemerintah, distribusi pendapatan, dan indeks pembangunan manusia memiliki dampak yang signifikan terhadap indeks pembangunan manusia. Sedangkan variabel DENS memiliki $p$-value di atas 0.1 , sehingga dapat disimpulkan bahwa kepadatan penduduk tidak memengaruhi PDRB per kapita.

- $\quad$ Pengujian hipotesis berganda (F-test)

Pada model regresi statistik uji $F$ untuk signifikansi secara umum (overall significance) adalah sebesar 2419.455. Statistik ini jauh lebih besar jika dibandingkan dengan nilai kritis dengan derajat bebas $q=4$ (numerator) dan $n-k-$ $1=198-4-1=194$ (denominator) sebesar $3.41(\alpha=$ 0.01). Dengan demikian, hipotesis nol bahwa secara bersama variabel penjelas tidak memberikan nilai tambah informasi dapat ditolak.

\subsection{Uji kelaikan suai (goodness of fit) persamaan $Y$}

Hasil estimasi (Tabel 5) memperlihatkan nilai adjusted $R$ squared sebesar 0.998 yang berarti bahwa variasi PDRB per kapita $(Y)$ dapat dijelaskan bersama-sama oleh variasi pengeluaran pemerintah $(G E)$, indeks gini $(G R)$, kepadatan penduduk (DENS), maupun indeks pembangunan manusia $(H D I)$ sebesar 99.8\% dan sisanya dijelaskan oleh variabel lain di luar model.

\subsection{Interpretasi parameter hasil estimasi}

Hasil estimasi persamaan dengan metode 2SLS menghasilkan persamaan $Y$ dengan model matematika sebagai berikut:

$$
\begin{gathered}
Y_{i t}=\beta_{0}+0.107 G E_{i t}+0.488 G R_{i t}{ }^{-} \\
0.106 \mathrm{DENS}+0.047 H D I_{i t}+u_{i t}(4)
\end{gathered}
$$

keterangan:

$\beta_{0 i}=$ konstanta masing-masing provinsi $i$ (Tabel 7)

Secara umum nilai koefisien variabel bebas bertanda positif, yang berarti bahwa variabel pengeluaran pemerintah $(G E)$, indeks gini $(G R)$, kepadatan penduduk (DENS), maupun indeks pembangunan manusia (HDI) berpengaruh positif terhadap PDRB per kapita $(Y)$. Koefisien variabel $G E$ sebesar 0.107 berarti bahwa setiap peningkatan $1 \%$ pengeluaran pemerintah terjadi peningkatkan PDRB per kapita sebesar $0.107 \%$ dengan asumsi variabel lain tetap (cateris paribus). Koefisien variabel GR sebesar 0.488 berarti bahwa setiap peningkatan $1 \%$ indeks gini maka terjadi peningkatan sebesar $0.488 \%$ pada PDRB per kapita dengan asumsi variabel lain tetap (cateris paribus).

Koefisien variabel HDI sebesar 0.047 berarti bahwa setiap peningkatan $1 \%$ indeks pembangunan manusia maka terjadi peningkatan sebesar $0.047 \%$ pada PDRB per kapita dengan asumsi variabel lain tetap (cateris paribus). Namun variabel kepadatan penduduk tidak berpengaruh secara signifikan terhadap PDRB per kapita. Hal ini dapat disebabkan oleh ketersediaan lapangan kerja belum yang bisa 
mengimbangi pertumbuhan jumlah tenaga kerja, rendahnya mobilitas, serta rendahnya tingkat produktivitas penduduk.

Nilai koefisien individu tiap provinsi (Tabel 6) menunjukkan modal awal (initial endowment) yang dimiliki suatu provinsi. Provinsi DKI Jakarta memiliki konstanta 13.06 yang merupakan tertinggi diantara 33 provinsi. Artinya dengan sedikit kenaikan nilai $G E, G R$, dan $H D I$, maka tingkat pendapatan perkapita $Y$ di Provinsi DKI Jakarta relatif tinggi dibandingkan provinsi lain. Sedangkan Provinsi Maluku memiliki nilai konstanta terkecil, yaitu 10.48 , memerlukan perubahan variabel eksogen yang relatif besar agar pendapatan perkapitanya bisa menyamai provinsi lainnya.

\section{Analisis Kinerja Pembangunan Manusia dan Pertumbuhan Ekonomi}

Pembangunan manusia yang tinggi memengaruhi proses pertumbuhan ekonomi, dan sebaliknya, pertumbuhan ekonomi yang tinggi memengaruhi kualitas pembangunan manusia. Namun tidak selalu pembangunan manusia yang tinggi disertai dengan pertumbuhan ekonomi yang tinggi pula, begitu pula sebaliknya. Capaian indeks pembangunan manusia dan PDRB per kapita masing-masing provinsi memiliki perbedaan yang cukup signifikan. Gambar 3 memperlihatkan kinerja HDI dan $Y$ pada 33 provinsi di Indonesia. Diagram sebaran kinerja $H D I$ dan $Y$ menunjukkan bahwa Provinsi DKI Jakarta merupakan provinsi dengan pembangunan manusia dan pertumbuhan ekonomi tertinggi di Indonesia, sedangkan Provinsi Kalimantan Timur, Kepulauan Riau, dan Riau adalah provinsi dengan pembangunan manusia dan pertumbuhan ekonomi di atas ratarata. Sementara itu, beberapa provinsi khususnya dari IBT yaitu Provinsi Nusa
Tenggara Barat, Nusa Tenggara Timur, Maluku Utara, dan Sulawesi Tenggara berada cukup jauh di bawah rata-rata nasional sehingga perlu diberikan perhatian khusus oleh pemerintah pusat.

Klasifikasi masing-masing provinsi (Tabel 8) menampilkan penggolongan berdasarkan kinerja indeks pembangunan manusia dan PDRB per kapita. Klasifikasi virtuous mengartikan bahwa provinsi tersebut menunjukkan kinerja indeks pembangunan manusia dan PDRB per kapita di atas rata-rata nasional. Sedangkan klasifikasi vicious memperlihatkan provinsi-provinsi yang memiliki kinerja indeks pembangunan manusia dan PDRB per kapita di bawah rata-rata nasional. Tabel 8 menunjukkan bahwa provinsi-provinsi di wilayah Indonesia Bagian Barat (IBB) relatif memiliki kinerja $H D I$ dan $Y$ yang lebih baik dibanding provinsi di Indonesia Bagian Timur (IBT). Sebanyak 10 dari 11 provinsi yang termasuk dalam kondisi vicious (HDI dan $Y$ rendah) berasal dari IBT, sedangkan 8 dari 11 provinsi yang termasuk dalam kondisi virtuous (HDI dan $Y$ tinggi) berasal dari IBB. Hal ini menggambarkan secara nyata kesenjangan antara provinsi di wilayah IBB dan IBT, baik dalam hal pembangunan manusia maupun pertumbuhan ekonomi.

Kemajuan beberapa provinsi disebabkan antara lain karena faktor sumberdaya yang tersedia, produktifitas, tingkat pendidikan penduduk, ketersediaan infrastruktur, maupun karena efisiensi dan efektifitas kebijakan pemerintah daerah. Beberapa provinsi diduga memiliki faktor lain di luar beberapa faktor tersebut. Misalnya keberhasilan pembangunan Provinsi DKI Jakarta tidak lepas dari peran pemerintah pusat yang sejak era orde lama menjadikan wilayah DKI Jakarta dan Pulau Jawa sebagai wilayah prioritas pembangunan. Hal tersebut membawa dampak ekonomi yang sangat signifikan dibandingkan provinsi lain, walaupun 
beberapa dekade ke belakang sudah mulai diakukan pemerataan dengan desentralisasi fiskal serta otonomi daerah.

Provinsi-provinsi di Pulau Jawa yang merupakan pulau dengan penduduk terpadat di Indonesia secara umum menunjukkan kinerja mendekati rata-rata, namun tidak terlihat signifikansinya bahkan tertinggal dari beberapa provinsi di Sumatera dan Kalimantan. Hal ini menunjukkan bahwa pertumbuhan penduduk yang terjadi akibat fertilitas maupun urbanisasi tidak diikuti dengan peningkatan produktifitas penduduk sehingga secara agregat pertambahan jumlah penduduk tidak membawa dampak yang signifikan terhadap pertumbuhan ekonomi. Berdasarkan data dari Kementrian Keuangan, secara umum pengeluaran per kapita pemerintah sejumlah provinsi di Pulau Jawa relatif lebih sedikit daripada provinsi lain. Provinsi Jawa Timur, Jawa Barat, dan Jawa Tengah merupakan 3 provinsi terbawah dalam alokasi anggaran belanja pemerintah maupun dalam alokasi belanja pendidikan per kapita. Hal ini mengindikasikan urgensi dari proporsionalitas pengalokasian dana dari pemerintah pusat kepada pemerintah daerah sebagai modal upaya penyediaan lapangan pekerjaan yang dapat mengimbangi pertumbuhan jumlah penduduk, peningkatan kualitas pendidikan, serta pemerataan pembangunan.

Beberapa provinsi di wilayah IBT berada dalam kondisi vicious dengan nilai IPM dan PDRB per kapita yang sangat rendah, seperti Provinsi Nusa Tenggara Barat dan Nusa Tenggara Timur. Hal ini dapat disebabkan oleh rata-rata lama sekolah yang berada jauh di bawah rata-rata nasional yaitu masingmasing hanya 6.6 tahun, berada pada

peringkat ke-31 dan 32 dari 33 provinsi. Selain itu, total pengeluaran pemerintah daerah dan belanja pemerintah daerah bidang pendidikan dan kesehatan kedua provinsi tersebut juga relatif rendah.

Provinsi Papua dan Papua Barat termasuk dalam kondisi looped economic growth dengan PDRB per kapita yang cukup tinggi namun memiliki IPM yang sangat rendah. Tingkat PDRB per kapita yang tinggi tidak serta merta menunjukkan bahwa setiap penduduk Papua mempunyai pendapatan di atas rata-rata. Data BPS menunjukkan bahwa rata-rata indeks gini Provinsi Papua tahun 2006-2011 merupakan yang tertinggi secara nasional dengan nilai sebesar 0.40 . UNDP (2011) menujukkan bahwa sebesar 36.4 persen masyarakat Provinsi Papua hidup di bawah garis kemiskinan, hampir tiga kali dari rata-rata nasional. Data tersebut menunjukkan bahwa terjadi kesenjangan pendapatan yang sangat signifikan di Provinsi Papua. Provinsi Papua Barat menunjukkan hal yang sedikit lebih baik namun tidak jauh berbeda. Nilai IPM dan PDRB per kapita berada di atas Provinsi Papua dengan indeks gini yang mendekati rata-rata nasional, yaitu sebesar 0.34 .

Kondisi looped human development memperlihatkan kondisi pembangunan manusia yang tinggi namun tidak disertai pertumbuhan ekonomi yang tinggi pula. Beberapa provinsi khususnya dari wilayah IBB masuk dalam klasifikasi ini, diantaranya Yogyakarta dan Bengkulu. Provinsi Yogyakarta memiliki nilai IPM yang cukup tinggi yaitu 75.01, berada di peringkat 4 teratas nasional, sedangkan PDRB per kapita berada di bawah ratarata dengan nilai sebesar 5,738 ribu rupiah. Begitu pula dengan Provinsi Bengkulu yang memiliki nilai IPM sebesar 72.31, berada di peringkat 10 nasional, namun PDRB per kapitanya hanya sebesar 4,596 ribu rupiah.

\section{KESIMPULAN DAN SARAN}

\section{Kesimpulan}

Hasil penelitian menunjukkan bahwa pemerintah daerah memegang 
peran penting dalam berhasil atau tidaknya pembangunan suatu wilayah. Belanja pemerintah di bidang pendidikan dan kesehatan terbukti berpengaruh secara positif dan signifikan dalam pembangunan manusia. Begitu juga dengan tingkat pendidikan yang memiliki pengaruh terhadap kapabilitas individu serta pemahaman teknologi sebagai syarat dari peningkatan produktivitas ekonomi.

Pengaruh pemerintah daerah dalam pembangunan ekonomi terlihat dalam perannya sebagai pengambil kebijakan penyediaan infrastruktur serta alokasi pengeluaran pemerintah. Pengeluaran pemerintah terbukti secara signifikan memengaruhi tingkat PDRB per kapita suatu wilayah. Penyediaan sarana fisik yang baik dapat meningkatkan mobilitas kegiatan ekonomi yang berpengaruh terhadap pertumbuhan ekonomi suatu daerah. Namun kinerja pertumbuhan ekonomi dan pembangunan manusia memperlihatkan kesenjangan yang signifikan antara provinsi di Indonesia Bagian Barat dan Indonesia Bagian Timur.

\section{DAFTAR PUSTAKA}

Basri, F. dan Munandar, H. 2009. Lanskap Ekonomi Indonesia: Kajian dan Renungan Terhadap Masalah-masalah Struktural, Transformasi Baru, dan Prospek Perekonomian Indonesia. Jakarta: Kencana.

Badan Pusat Statistik. 2012. Statistik Indeks Pembangunan Manusia. Jakarta: BPS.

Perkembangan

Beberapa Indikator Utama SosialEkonomi Tahun 2008-2011. Jakarta: BPS.
PDRB Menurut Penggunaan Tahun 2006-2011. Jakarta: BPS.

Statistik

Keuangan Provinsi Tahun 20062011. Jakarta: BPS.

Brata, A.G. 2002. "Pembangunan Manusia dan Kinerja Ekonomi Regional di Indonesia". Jurnal Ekonomi Pembangunan: Kajian Ekonomi Negara Berkembang. 7:133-122.

Gujarati, D.N. 2004. Basic Econometrics. Ed ke-4. Singapore: McGraw-Hill.

Hausman, J.A. 1978. "Spesification Test in Econometrics". Econometrica. 46:1251-1271.

Ramirez, A., Ranis, G. dan Stewart, F.. 1998. "Economic Growth and Human Capital". QEH Working Paper No. 18.

Ranis, G. dan Stewart, F. 2006. "Successful Transition towards a Virtuous Cycle of Human Development and Economic Growth: Country Studies". Center Discussion Paper No. 943.

Ranis, G., Stewart, F. dan Ramirez, A. 2000. "Economic Growth and Human Development". World Development. 28:197-219.

Ranis, G. 2004. "Human Development and Economic Growth". Center Discussion Paper No. 887.

Pindyck, R.S. dan Rubinfeld, D.L. 1998. Econometric Models and Economic Forecasts. Ed ke-4. Michigan: Irwin/McGraw-Hill.

Tjiptoherijanto, P. 1996. Sumber Daya Manusia dalam Pembangunan Nasional. Jakarta: Lembaga Penerbit Fakultas Ekonomi Universitas Indonesia.

UNDP Indonesia. 2011. Annual Report UNDP 2011/2012. Jakarta: UNDP. 


\section{Lampiran}

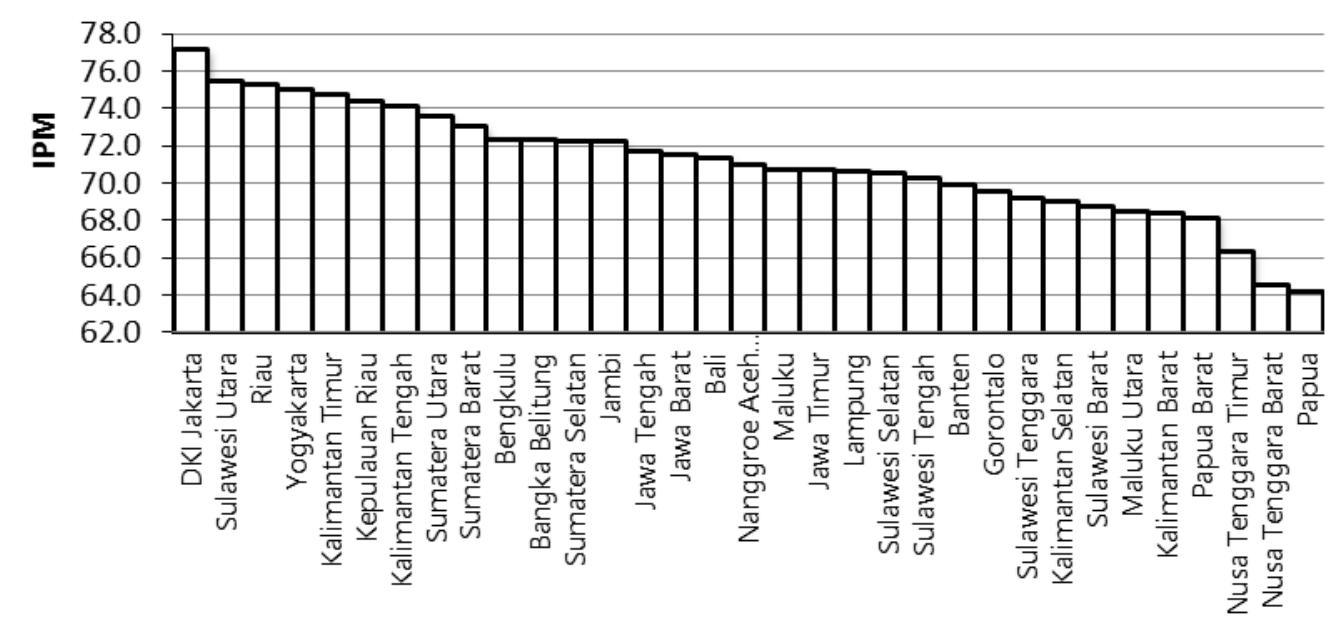

Gambar 2 Nilai rata-rata indeks pembangunan manusia menurut provinsi tahun

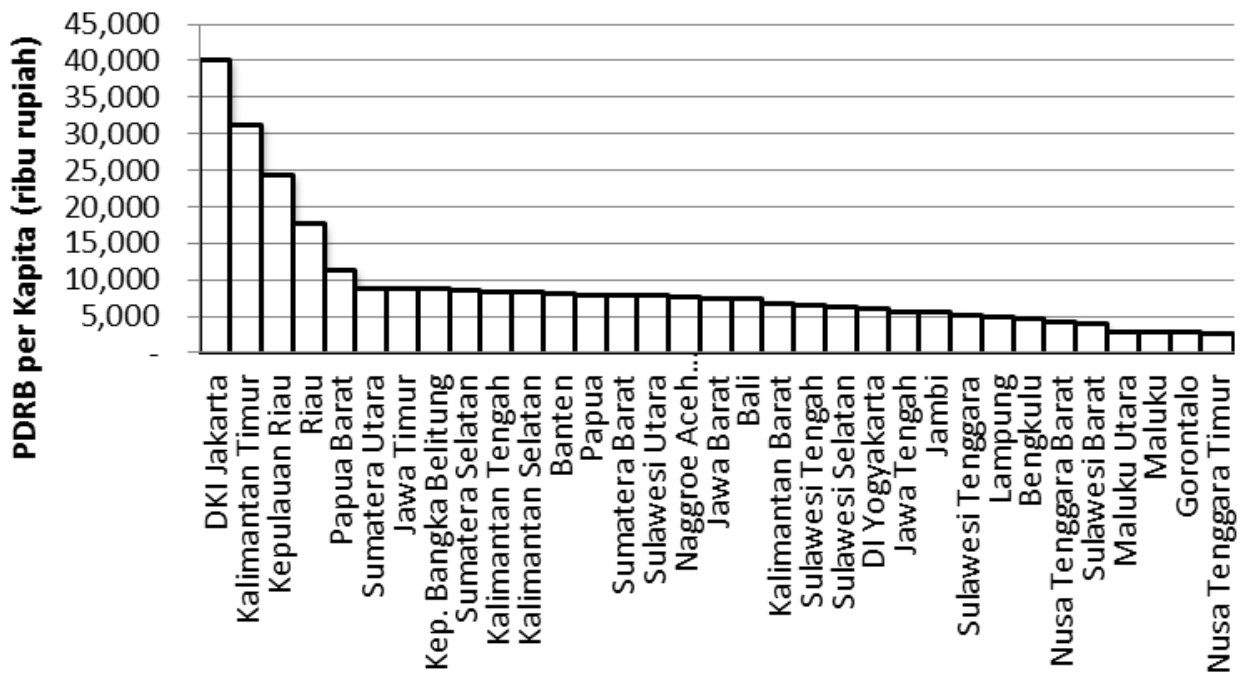

Gambar 1 Nilai rata-rata PDRB per kapita menurut provinsi tahun 20062011 


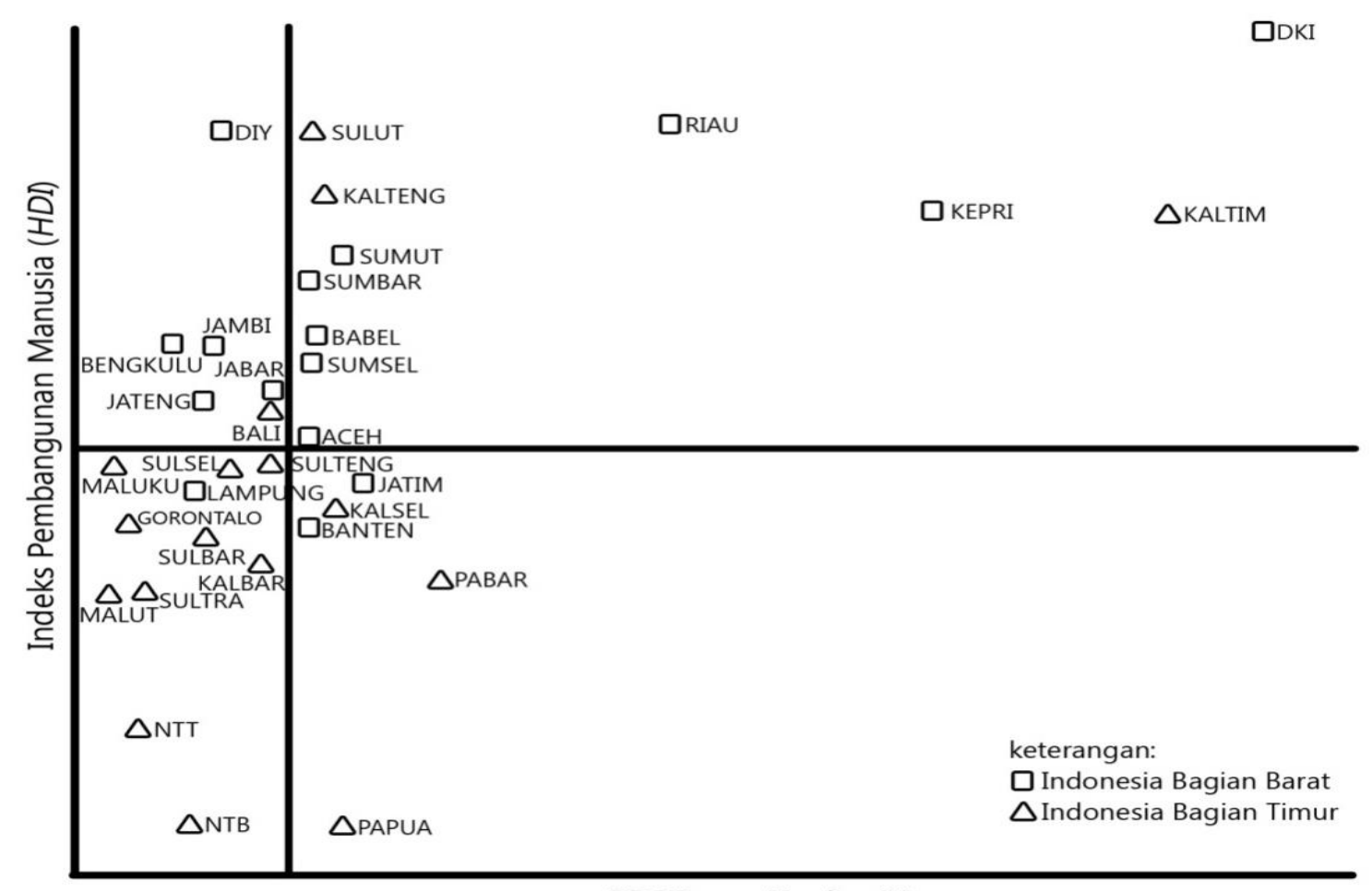

PDRB per Kapita ( $Y$ )

Gambar 3 Kinerja IPM dan PDRB per kapita menurut provinsi tahun 2006-2011 
Tabel 1 Jenis dan sumber data penelitian

\begin{tabular}{|c|c|c|}
\hline $\begin{array}{l}\text { Nama } \\
\text { variabel }\end{array}$ & Data yang dianalisis & Sumber data \\
\hline$H D I_{i t}$ & $\begin{array}{l}\text { Indeks pembangunan manusia } \\
\text { menurut provinsi tahun 2006- } \\
2011\end{array}$ & $\begin{array}{l}\text { [BPS] Badan Pusat Statistik, } \\
\text { Statistik Indeks Pembangunan } \\
\text { Manusia }\end{array}$ \\
\hline$Y_{i t}$ & $\begin{array}{l}\text { PDRB per kapita menurut harga } \\
\text { konstan tahun } 2000 \text { per provinsi } \\
\text { tahun 2006-2011 }\end{array}$ & $\begin{array}{l}\text { [BPS] Badan Pusat Statistik, } \\
\text { PDRB Provinsi Menurut } \\
\text { Penggunaan }\end{array}$ \\
\hline PSPEND $_{i t}$ & $\begin{array}{l}\text { Belanja pemerintah provinsi } \\
\text { bidang pendidikan dan kesehatan } \\
\text { tahun } 2006-2011 \text { per jumlah } \\
\text { penduduk }\end{array}$ & $\begin{array}{l}\text { Kementerian Keuangan, } \\
\text { Realisasi APBD }\end{array}$ \\
\hline$E D U_{i t}$ & $\begin{array}{l}\text { Rata-rata lama sekolah penduduk } \\
\text { usia } 15 \text { tahun ke atas menurut } \\
\text { provinsi dan jenis kelamin tahun } \\
2006-2011\end{array}$ & $\begin{array}{l}\text { [BPS] Badan Pusat Statistik, } \\
\text { Perkembangan Beberapa } \\
\text { Indikator Utama Sosial- } \\
\text { Ekonomi Indonesia }\end{array}$ \\
\hline$G E_{i t}$ & $\begin{array}{l}\text { Jumlah total pengeluaran } \\
\text { pemerintah provinsi tahun 2006- } \\
2011 \text { per jumlah penduduk }\end{array}$ & $\begin{array}{l}\text { [BPS] Badan Pusat Statistik, } \\
\text { Statistik Keuangan Provinsi }\end{array}$ \\
\hline$G R_{i t}$ & $\begin{array}{l}\text { Indeks gini provinsi tahun 2006- } \\
2011\end{array}$ & $\begin{array}{l}\text { [BPS] Badan Pusat Statistik, } \\
\text { Perkembangan Beberapa } \\
\text { Indikator Utama Sosial- } \\
\text { Ekonomi Indonesia }\end{array}$ \\
\hline$D E N S_{i t}$ & $\begin{array}{l}\text { Kepadatan penduduk per } \\
\text { provinsi tahun 2006-2011 }\end{array}$ & $\begin{array}{l}\text { [BPS] Badan Pusat Statistik, } \\
\text { Perkembangan Beberapa } \\
\text { Indikator Utama Sosial- } \\
\text { Ekonomi Indonesia }\end{array}$ \\
\hline
\end{tabular}

Tabel 2 Hasil uji $F$-statistik

\begin{tabular}{cccccc}
\hline Persamaan & $R S S_{1}$ & $R S S_{2}$ & $\begin{array}{c}F- \\
\text { statistik }\end{array}$ & $\begin{array}{c}F \text {-tabel } \\
(\alpha=0.01)\end{array}$ & $\begin{array}{c}\text { Model yang } \\
\text { digunakan }\end{array}$ \\
\hline$H D I$ & 1060.947 & 43.25535 & 143.3709 & 1.79 & fixed effect \\
$Y$ & 38.89296 & 0.438975 & 533.8094 & 1.79 & fixed effect \\
\hline
\end{tabular}

Tabel 3 Hasil uji hausman

\begin{tabular}{ccccc}
\hline Persamaan & $\chi^{2}$ & d.f. & $\chi^{2}$ tabel & $\begin{array}{c}\text { Model yang } \\
\text { digunakan }\end{array}$ \\
\hline HDI & 21.713536 & 3 & $12.838(\alpha=0.005)$ & fixed effect \\
$Y$ & 18.990745 & 4 & $14.860(\alpha=0.005)$ & fixed effect \\
\hline
\end{tabular}


Tabel 4 Hasil estimasi persamaan pembangunan manusia (HDI)

\begin{tabular}{ccc}
\hline Variabel & \multicolumn{2}{c}{ Variabel Dependen } \\
Independen & Koefisien & $p$-value \\
\cline { 2 - 3 } & $-69.14113^{*}$ & 0.0000 \\
Konstanta & $0.469164^{*} *$ & 0.0285 \\
EDU & $0.297970^{*}$ & 0.0000 \\
PSPEND & $8.454802^{*}$ & 0.0000 \\
$Y$ & & 0.989952 \\
Adj. $R^{2}$ & & $0.000000^{*}$ \\
Prob. $F$ & &
\end{tabular}

aKeterangan: * signifikan pada tingkat kesalahan $(a)=0.01$ ** signifikan pada tingkat kesalahan $(a)=0.05$

Tabel 5 Hasil estimasi persamaan PDRB per kapita $(Y)$

\begin{tabular}{ccc}
\hline \multirow{2}{*}{$\begin{array}{c}\text { Variabel } \\
\text { Independen }\end{array}$} & \multicolumn{2}{c}{ Variabel Dependen } \\
\cline { 2 - 3 } & Koefisien & $p$-value \\
\cline { 2 - 3 } & $11.56138^{*}$ & 0.0000 \\
Konstanta & $0.107174^{*}$ & 0.0001 \\
GE & $0.488091^{*}$ & 0.0000 \\
GR & -0.105842 & 0.3782 \\
DENS & $0.047338^{*}$ & 0.0000 \\
HDI & & 0.998604 \\
Adj. $R^{2}$ & & $0.0000^{*}$ \\
Prob. F & & \\
\hline
\end{tabular}

aKeterangan: * signifikan pada tingkat kesalahan $(a)=0.01$

Tabel 6 Hasil estimasi persamaan simultan dengan metode 2SLS

\begin{tabular}{ccccc}
\hline Variabel & \multicolumn{4}{c}{ Variabel dependen } \\
\cline { 2 - 5 } independen & \multicolumn{3}{c}{$H D I$} & \multicolumn{3}{c}{$Y$} \\
\cline { 2 - 5 } & Koefisien & $p$-value & Koefisien & $p$-value \\
\hline Konstanta & $-69.14133^{*}$ & 0.0000 & $11.56138^{*}$ & 0.0000 \\
EDU & $0.469164^{*}$ & 0.2850 & - & - \\
PSPEND & $0.297970^{*}$ & 0.0000 & - & - \\
$Y$ & $8.454802^{*}$ & 0.0000 & - & - \\
$G E$ & - & - & $11.56138^{*}$ & 0.0001 \\
$G R$ & - & - & $0.107174^{*}$ & 0.0000 \\
DENS & - & - & -0.105842 & 0.3782 \\
HDI & - & - & $0.047338^{*}$ & 0.0000 \\
\hline Adj. $R^{2}$ & & 0.989952 & & 0.998604 \\
Prob. $F$ & & $* 0.0000$ & $* 00000$ \\
\hline
\end{tabular}

${ }^{\mathrm{a}}$ Keterangan: $*$ signifikan pada tingkat kesalahan $(\alpha)=0.01$

$* *$ signifikan pada tingkat kesalahan $(\alpha)=0.05$ 
Tabel 7 Klasifikasi provinsi berdasarkan kinerja HDI dan $Y$ tahun 2006-2011

\begin{tabular}{|c|c|}
\hline $\begin{array}{c}\text { Virtuous } \\
\text { (HDI dan } Y \text { Tinggi) }\end{array}$ & $\begin{array}{c}\text { Vicious } \\
\text { (HDI dan } Y \text { Rendah) }\end{array}$ \\
\hline Nanggroe Aceh Darussalam & Lampung \\
\hline Sumatera Utara & Nusa Tenggara Barat \\
\hline Sumatera Barat & Nusa Tenggara Timur \\
\hline Riau & Kalimantan Barat \\
\hline Kepulauan Riau & Gorontalo \\
\hline Sumatera Selatan & Sulawesi Tengah \\
\hline Bangka Belitung & Sulawesi Selatan \\
\hline DKI Jakarta & Sulawesi Barat \\
\hline Kalimantan Tengah & Sulawesi Tenggara \\
\hline Kalimantan Timur & Maluku \\
\hline Sulawesi Utara & Maluku Utara \\
\hline $\begin{array}{c}\text { Looped HDI } \\
\text { (HDI Tinggi, } Y \text { Rendah) }\end{array}$ & $\begin{array}{c}\text { Looped } Y \\
\text { (HDI Rendah, } Y \text { Tinggi) }\end{array}$ \\
\hline Jambi & Banten \\
\hline Bengkulu & Jawa Timur \\
\hline Jawa Barat & Kalimantan Selatan \\
\hline Jawa Tengah & Papua \\
\hline $\begin{array}{l}\text { DI. Yogyakarta } \\
\text { Bali }\end{array}$ & Papua Barat \\
\hline
\end{tabular}

Tabel 8 Hasil estimasi persamaan pembangunan manusia (HDI)

\begin{tabular}{lll}
\hline \multirow{2}{*}{$\begin{array}{l}\text { Variabel } \\
\text { Independen }\end{array}$} & \multicolumn{2}{c}{ Variabel Dependen } \\
\cline { 2 - 3 } & Koefisien & p-value \\
\hline Konstanta & $-69.14113^{*}$ & 0.0000 \\
EDU & $0.469164^{* *}$ & 0.0285 \\
PSPEND & $0.297970^{*}$ & 0.0000 \\
$Y$ & $8.454802^{*}$ & 0.0000 \\
\hline Adj. $R^{2}$ & & 0.989952 \\
Prob. F & & $0.000000^{*}$ \\
\hline
\end{tabular}

${ }^{a}$ Keterangan: $*$ signifikan pada tingkat kesalahan $(\alpha)=0.01$ ** signifikan pada tingkat kesalahan $(\alpha)=0.05$ 
Tabel 9 Nilai konstanta masing-masing provinsi pada persamaan $Y$

\begin{tabular}{lc}
\hline Provinsi & Konstanta \\
& $\left(\beta_{0}\right)$ \\
\hline DKI Jakarta & 13.06 \\
Kepulauan Riau & 12.65 \\
Kalimantan Timur & 12.57 \\
Riau & 12.17 \\
Jawa Timur & 12.05 \\
Banten & 11.99 \\
Jawa Barat & 11.87 \\
Sumatera Utara & 11.77 \\
Kalimantan Selatan & 11.76 \\
Bali & 11.74 \\
Papua Barat & 11.72 \\
Sumatera Selatan & 11.67 \\
Papua & 11.67 \\
Kep. Bangka Belitung & 11.65 \\
Jawa Tengah & 11.60 \\
Sumatera Barat & 11.58 \\
Aceh & 11.54 \\
Kalimantan Barat & 11.53 \\
Sulawesi Selatan & 11.50 \\
Nusa Tenggara Barat & 11.48 \\
Sulawesi Utara & 11.45 \\
Sulawesi Tengah & 11.40 \\
DI Yogyakarta & 11.40 \\
Kalimantan Tengah & 11.38 \\
Lampung & 11.34 \\
Sulawesi Tenggara & 11.21 \\
Jambi & 11.20 \\
Bengkulu & 11.04 \\
Nulawesi Barat & 11.03 \\
Maluku Utara & 10.83 \\
Gorontalo & 10.60 \\
Maluku & 10.59 \\
\hline
\end{tabular}

